\title{
Federal Mandates with Local Agenda Setters
}

\author{
Jacques Crémer \\ CNRS-GREMAQ and IDEI
}

\author{
Thomas R. Palfrey \\ California Institute of Technology
}

October 27, 2000

\begin{abstract}
$\underline{\text { Abstract }}$
This paper investigates the effect of local monopoly agenda setting on federal standards. Federal standards specify a minimum (or maximum) point in policy space which can be raised (or lowered) by local option. Without local agenda setters, this creates incentives for nonmajoritarian outcomes, with a tendency for policies to be too high (low). Local agenda setters may have incentives to distort these outcomes even further. We demonstrate that federal standards can counterbalance the distortions of local agenda setters.
\end{abstract}

